\title{
Platelet-Derived Growth Factor Subunit A
}

National Cancer Institute

\section{Source}

National Cancer Institute. Platelet-Derived Growth Factor Subunit A. NCI Thesaurus.

Code C30162.

Platelet-derived growth factor subunit A (211 aa, $\sim 24 \mathrm{kDa}$ ) is encoded by the human

PDGFA gene. This protein plays a role in the regulation of chemotaxis, cell migration, cell survival, cell proliferation, and embryonic development. 